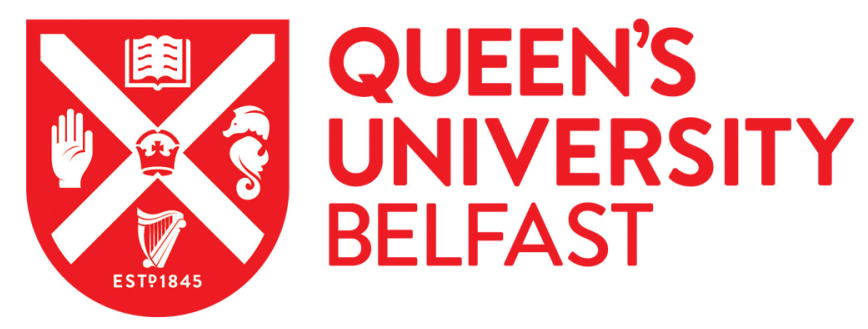

\title{
Development and in-house validation of a rapid and simple to use ELISA for the detection and measurement of the mycotoxin sterigmatocystin
}

Oplatowska-Stachowiak, M., Reiring, C., Sajic, N., Haasnoot, W., Brabet, C., Campbell, K., Elliott, C. T., \& Salden, M. (2018). Development and in-house validation of a rapid and simple to use ELISA for the detection and measurement of the mycotoxin sterigmatocystin. Analytical and Bioanalytical Chemistry.

https://doi.org/10.1007/s00216-018-0988-8

Published in:

Analytical and Bioanalytical Chemistry

Document Version:

Peer reviewed version

Queen's University Belfast - Research Portal:

Link to publication record in Queen's University Belfast Research Portal

\section{Publisher rights}

Copyright Springer-Verlag GmbH Germany, part of Springer Nature 2018. This work is made available online in accordance with the publisher's policies. Please refer to any applicable terms of use of the publisher.

\section{General rights}

Copyright for the publications made accessible via the Queen's University Belfast Research Portal is retained by the author(s) and / or other copyright owners and it is a condition of accessing these publications that users recognise and abide by the legal requirements associated with these rights.

Take down policy

The Research Portal is Queen's institutional repository that provides access to Queen's research output. Every effort has been made to ensure that content in the Research Portal does not infringe any person's rights, or applicable UK laws. If you discover content in the Research Portal that you believe breaches copyright or violates any law, please contact openaccess@qub.ac.uk. 


\section{Abstract}

\section{Development and in-house validation of a rapid and simple to use ELISA} for the detection and measurement of the mycotoxin sterigmatocystin

${ }^{a}$ EuroProxima B.V., Beijerinckweg 18, 6827 BN Arnhem, The Netherlands

${ }^{b}$ RIKILT Wageningen UR, Akkermaalsbos 2, 6708 WB Wageningen, The Netherlands

${ }^{c}$ Centre de Coopération Internationale en Recherche Agronomique pour le Développement (CIRAD), UMR QualiSud, 73 rue Jean-François Breton, 34398 Montpellier Cedex 5, France

${ }^{d}$ QualiSud, Université Montpellier, CIRAD, Montpellier SupAgro, Université d'Avignon, Université de La Réunion, Montpellier, France

'Institute for Global Food Security, School of Biological Sciences, Queen's University Belfast, 1830 Malone Road, Belfast BT95BN, UK

*Corresponding author. Email: michalina.oplatowska@europroxima.com

Sterigmatocystin (STG) is a highly toxic secondary fungal metabolite structurally closely related to the well-known carcinogenic aflatoxins. Its presence has been reported in grains and grain based products as well as in other foodstuffs like nuts, green coffee beans, spices, beer and cheese. Due to the lack of suitable data on the occurrence of STG, in 2013 the European Food Safety Authority (EFSA) could not characterize its risk for human health and recommended that more data on STG in food and feed needed to be collected. In order to provide a new tool for the specific detection of STG, a competitive enzyme-linked immunosorbent assay (ELISA) was developed, optimized and validated in this study based on a sensitive monoclonal antibody specific to STG with no cross-reactivity with aflatoxins. The sample preparation method for rice, wheat and maize was based on a modified QuEChERS (quick, easy, cheap, effective, rugged and safe) approach. The assay was validated for the detection of STG in rice, wheat and maize in accordance with the guidelines for validation of semi-quantitative screening methods included in Commission Regulation (EU) 519/2014. The screening target concentration (STC) was set at 1.5 $\mu \mathrm{g} / \mathrm{kg}$. The cut offs for rice, wheat and maize were 1.2, 1.2 and $1.3 \mu \mathrm{g} / \mathrm{kg}$ and the false suspected rates were $0.34 \%, 1.15 \%$ and $0.78 \%$, respectively. Good correlation was found between the results obtained by the STG ELISA and LC-MS/MS method for naturally contaminated rice 
samples. This validated method can be applied as a sensitive and high-throughput screening for

35 the presence of STG in a range of agricultural commodities.

36

37

38

39

40

41

42

43

44

45

46

47

48

49

50

51

52

\section{Keywords}

Enzyme-linked immunosorbent assay, food safety, immunoassay, mycotoxin

\section{Introduction}

Mycotoxins are toxic secondary metabolites produced by fungi belonging to Aspergillus, Fusarium and Penicillium species. They can contaminate agricultural commodities during production, storage, processing and transport. The ingestion of contaminated products can cause a variety of adverse effects in both humans and animals. There are between $300-400$ mycotoxins known to humans [1]. Regulatory bodies in many countries worldwide have set limits for the most toxic mycotoxins in food in order to protect human health. In the European Union (EU) there are maximum, indicative or guidance limits for well-known and harmful mycotoxins such as aflatoxins, ochratoxin A, fumonisins, zearalenone, deoxynivalenol, T-2/HT-2 toxins, patulin and citrinin in food and feed commodities (Commission Regulation (EC) 1881/2006 [2]; Commission Recommendation 2006/576/EC [3]; Commission Recommendation 2013/165/EU [4]). Among these toxins, aflatoxins are the most potent carcinogens found in nature, classified as group 1 carcinogens (carcinogenic to humans) by the International Agency for Research on Cancer [5]. They occur in corn, peanuts, rice, soybean, nuts and other crops. Structurally related sterigmatocystin (STG) (Fig. 1) is a toxin that shares the biosynthetic pathway with aflatoxins [6]. It is produced mainly by Aspergillus species such as $A$. nidulans and $A$. versicolor, which can infect crops post-harvest. STG accumulation has been reported in grains but also nuts, green coffee beans, spices, beer and cheese. STG is considered to be a potential carcinogen, mutagen and teratogen [7] and it was included in group 2B agents (possibly carcinogenic to humans) by IARC [8]. The data on its occurrence and toxicity are limited, therefore in most countries there are no regulatory limits concerning this toxin in contrast to aflatoxins. In the past, only the Czech Republic and Slovakia prior to entering the EU had maximum limits for STG of $5 \mu \mathrm{g} / \mathrm{kg}$ and 20 $\mu \mathrm{g} / \mathrm{kg}$ in different agricultural commodities [9]. According to EFSA, STG concentration from 1.5 to $8 \mu \mathrm{g} / \mathrm{kg}$ in grains and grain-based products constitutes a low health concern [6]. EFSA has also recommended to collect more data on the occurrence of STG in food and feed using analytical methods with an LOQ at least $1.5 \mu \mathrm{g} / \mathrm{kg}$. In response to this call, the survey on STG in food was 
performed [10]. A total of 1259 samples of cereal grains, cereal products, beer and nuts collected in Europe between 2013 and 2014 were analysed by LC-MS/MS methods. The authors found low levels of STG contamination mainly in all unprocessed rice, $21 \%$ of the processed rice and $22 \%$ of oat samples analysed. In a previous survey including Latvian grains - wheat, barley, oat, buckwheat and rye-13 out of 95 sample and 42 out of 120 samples, from 2006 and 2007 harvests, respectively, were found to contain STG [11].

STG can be detected using thin layer chromatography [9] or HPLC [12]. LC-MS/MS methods have also been developed for the detection of STG in food and feed such as wheat, rice, oat, rye, maize and barley [13]; white rice and sorghum [14]; beer and cheese [12]; feed [15]. STG is also commonly included in many LC-MS/MS multi-mycotoxin methods [16-20]. As a lower cost alternative, immunochemical methods can be used for screening purposes. Enzyme-linked immunosorbent assay (ELISA) is still the most popular in the field due to its simplicity, highthroughput and cost-effectiveness. However, for STG detection only a few ELISA tests have been developed so far (Table 1). Kong et al. [21] obtained a sensitive monoclonal antibody (mAb) and used it to develop an indirect competitive ELISA with an IC $\mathrm{C}_{50}$ (50\% inhibitory concentration) of $0.092 \mathrm{ng} / \mathrm{ml}$ for the detection of $1.2 \mu \mathrm{g} / \mathrm{kg}$ of STG in cereals. Li et al. [22] developed an indirect competitive ELISA based on a mAb with an $\mathrm{IC}_{50}$ of $0.36 \mathrm{ng} / \mathrm{ml}$ for the analysis of wheat, maize and peanuts. The method was rather time-consuming and expensive as it required the application of an immunoaffinity chromatography step during the sample preparation procedure. It was also based on matrix-matched calibration in order to reduce matrix effect, so the standards for calibration had to be prepared in blank matrix for each experiment. Li et al. [23] presented an indirect competitive ELISA based on an antibody with an $\mathrm{IC}_{50}$ of $2.5 \mathrm{ng} / \mathrm{ml}$. The assay was validated only for wheat at relatively high concentrations. Another immunochemical method lateral flow immunochromatographic strip - was also developed by Kong et al. [21] with a visual limit of detection (LOD) of 3, 1.2 and $3 \mu \mathrm{g} / \mathrm{kg}$ for wheat, maize and rice, respectively.

In order to provide a new tool for the fast and sensitive detection of STG in cereals a direct competitive ELISA was developed in the presented research based on a new mAb. While there are currently no legal limits for STG, EFSA recommends to use analytical methods for STG with an LOQ of at least $1.5 \mu \mathrm{g} / \mathrm{kg}$ [6]. The developed ELISA aimed to be able to detect the STG in different cereals at this level. Another goal of this study was also to validate the developed method in accordance with the guidance for validation of semi-quantitative screening methods for mycotoxins included in Commission Regulation (EU) 519/2014 [24]. 
Table 1. Comparison of published ELISA formats, applied matrices and extraction methods for

102 STG with the method developed in this research.

\begin{tabular}{|c|c|c|c|c|c|}
\hline Reference & Method & $\begin{array}{l}\mathrm{IC}_{50} \\
{[\mathrm{ng} / \mathrm{ml}]}\end{array}$ & Matrices & Extraction method & Validation \\
\hline $\begin{array}{l}\text { Presented } \\
\text { method }\end{array}$ & $\begin{array}{l}\text { dc- } \\
\text { ELISA }\end{array}$ & 0.64 & $\begin{array}{l}\text { rice, } \\
\text { wheat, } \\
\text { maize }\end{array}$ & $\begin{array}{l}\text { 95\% ACN extraction and } \\
\text { defatting with n- } \\
\text { heptane, purification } \\
\text { with PSA sorbent, } \\
\text { evaporation, } \\
\text { reconstitution }\end{array}$ & $\begin{array}{l}\text { Screening target } \\
\text { concentration (STC) } \\
1.5 \mu \mathrm{g} / \mathrm{kg} \text {, samples } \\
\text { spiked at } 1.5,3 \text { and } \\
6 \mu \mathrm{g} / \mathrm{kg}\end{array}$ \\
\hline [21] & ic-ELISA & 0.092 & $\begin{array}{l}\text { rice, } \\
\text { wheat, } \\
\text { maize }\end{array}$ & $\begin{array}{l}60 \% \mathrm{MeOH} \text { extraction, } \\
\text { dilution }\end{array}$ & $\begin{array}{l}\text { Samples spiked at } \\
1.2,2.4 \text { and } 6 \mu \mathrm{g} / \mathrm{kg}\end{array}$ \\
\hline [22] & ic-ELISA & 0.36 & $\begin{array}{l}\text { wheat, } \\
\text { maize, } \\
\text { peanut }\end{array}$ & $\begin{array}{l}\text { 80\% MeOH extraction, } \\
\text { immunoaffinity } \\
\text { chromatography }\end{array}$ & $\begin{array}{l}\text { Samples spiked at } \\
5,10 \text { and } 20 \mu \mathrm{g} / \mathrm{kg}\end{array}$ \\
\hline [23] & ic-ELISA & 2.5 & wheat & $90 \% \mathrm{MeOH}$ extraction & $\begin{array}{l}\text { Samples spiked at } \\
8-500 \mu \mathrm{g} / \mathrm{kg}\end{array}$ \\
\hline
\end{tabular}

dc - ELISA direct competitive ELISA

ic - indirect competitive ELISA

\section{Materials and methods}

\section{Chemicals, consumables $\&$ apparatus}

STG, aflatoxins $\left(B_{1}, B_{2}, G_{1}, G_{2}\right.$ and $\left.M_{1}\right)$, acetonitrile ( $\left.A C N\right)$, methanol (MeOH), acetone, chloroform, n-heptane, sulphuric acid, disodium hydrogen phosphate, sodium dihydrogen phosphate, potassium dihydrogen phosphate, sodium carbonate, sodium bicarbonate, sodium chloride, magnesium sulphate, Tween 20, bovine serum albumin (BSA), keyhole limpet hemocyanin (KLH), horseradish peroxidase (HRP), sodium borohydride and dimethylformamide (DMF) were purchased from Sigma-Aldrich (Dorset, UK \& Zwijndrecht, the Netherlands). Primary-secondary amine (PSA) bulk sorbent was purchased from Agilent (Amstelveen, the Netherlands). Substrate 3,3',5,5'-tetramethylbenzidine (TMB) for HRP enzyme was obtained from Neogen (Lansing, USA). Samples were blended using IKA A11 Basic laboratory mill (IKA, Staufen, Germany) and centrifuged in Sigma 4K10 centrifuge (Sigma, Osterode am Harz, Germany). Microtiter plates were read on BioTek EL808 type ELISA plate reader (BioTek, Bad Friedrichshall, Germany).

\section{Production of STG conjugates}

The immunogen (STG-BSA) and the coating antigen (STG-KLH) were produced in accordance with the method published by Li et al. [23] and Kononenko et al. [25]. STG was first converted to hemiacetal by heating with acid and then conjugated to proteins by reductive alkylation with 
125 sodium borohydride. In short, $2.5 \mathrm{mg}$ of STG was dissolved in $1.25 \mathrm{ml}$ of acetone and $0.03 \mathrm{ml}$ of

$12610 \%$ sulphuric acid was added. The solution was refluxed for $4 \mathrm{~h}$ at $56^{\circ} \mathrm{C}$ and then the solvent was

127 evaporated to dryness under a stream of nitrogen. The residue was dissolved in $10 \mathrm{ml}$ of water

128 and extracted three times with $5 \mathrm{ml}$ of chloroform. Combined chloroform was then washed with

$1295 \mathrm{ml}$ of water and dried above sodium sulphate for $30 \mathrm{~min}$. Next, sodium sulphate was filtered

130 and the solvent was evaporated to dryness. The yellow residue was dissolved in $500 \mu \mathrm{l}$ of DMF.

131 Half of the STG hemiacetal solution was added to $5 \mathrm{mg}$ of BSA dissolved in $1.5 \mathrm{ml}$ of water and

132 half to $5 \mathrm{mg}$ of $\mathrm{KLH}$ solution. The solutions were mixed for $1 \mathrm{~h}$ at room temperature. Then $50 \mu \mathrm{l}$

133 of sodium borohydride solution at the concentration of $1 \mathrm{mg} / \mathrm{ml}$ was added and the reaction

134 mixture was refrigerated for $1 \mathrm{~h}$. Finally, the conjugates were purified by dialysis against $0.1 \mathrm{M}$

135 phosphate buffer $\mathrm{pH} 8.0$ with three changes of the dialyzing solution. The conjugates were stored

136 at $-20^{\circ} \mathrm{C}$. STG-HRP was produced in a similar way, first by converting $2.5 \mathrm{mg}$ of STG to hemiacetal

137 and then conjugating it to $10 \mathrm{mg}$ of HRP.

\section{Monoclonal antibodies production}

Fifteen $\mu \mathrm{g}$ of STG-BSA conjugate per injection was used to immunise two mice in accordance with the procedure described in details in [26]. The blood samples collected from animals 10 days after each injection were screened in antigen-coated ELISA [26]. STG-KLH conjugate at the concentration of $1 \mu \mathrm{g} / \mathrm{ml}$ was used as a coating antigen. The animal showing the best response in terms of antibody titre and sensitivity after 3 immunisations was euthanised. Its spleen was removed and the splenocytes were fused with SP2 myeloma cells in accordance with the procedure described by Köhler and Milstein for the first time in 1975 [27]. The detailed procedures for fusion, screening, large scale antibody production in flasks and antibody purification are described in [26].

\section{STG ELISA}

153 The microtiter ELISA plates were first coated with polyclonal rabbit anti-mouse antibody. 154 Hundred $\mu \mathrm{l}$ of $10 \mu \mathrm{g} / \mathrm{ml}$ solution of this antibody in phosphate buffered saline (PBS) pH 7.4 was 155 added to each well of the plate and incubated overnight at room temperature. Then the solution 156 was discarded and the plate was used for the STG ELISA. For calibration, a seven-point standard 157 curve for STG in PBS pH 7.4 containing 1\% BSA (assay buffer) was prepared. The concentrations of standards were $0,0.125,0.25,0.5,1,2$ and $4 \mathrm{ng} / \mathrm{ml}$. Fifty $\mu$ l of standards or extracted samples 
159 were added in duplicate to the wells of the plate. Then $25 \mu \mathrm{l}$ of the monoclonal anti-STG antibody

$160(2 \mathrm{mg} / \mathrm{ml}$ stock diluted $1 / 4000$ in the assay buffer $)$ and $25 \mu \mathrm{l}$ of the STG-HRP conjugate $(1 \mathrm{mg} / \mathrm{ml}$

161 stock diluted 1/1000 in the assay buffer) were added to each well. The plate was incubated at

$162 \quad 20-25^{\circ} \mathrm{C}$ in the dark for $90 \mathrm{~min}$. Then the solution was removed and the plate was washed 3 times

163 with rinsing buffer (PBS containing $0.05 \%$ Tween 20). Hundred $\mu$ l of TMB substrate was added to

164 each well and then the colour was developed for $30 \mathrm{~min}$ at $20-25^{\circ} \mathrm{C}$ in the dark. The absorbance

165 was recorded at $450 \mathrm{~nm}$ on a microtiter plate reader after stopping the enzymatic reaction with

$166100 \mu$ l of sulphuric acid.

167

\section{Samples}

169 For the STG ELISA validation cereal samples: wheat, maize and rice (5 different types of each, 4

170 samples of each type) were obtained from local stores. Seven naturally contaminated rice

171 samples and one sample not containing STG were obtained from CIRAD, France and analysed by

172 a multiplex mycotoxins method [20]. The concentrations of STG found to be present in these

173 samples were as follows: $1.20,1.25,1.56,1.70,4.83$ and $7.8 \mu \mathrm{g} / \mathrm{kg}$.

\section{Sample preparation}

176 The extraction procedure was based on the method developed by Zhao et al. [13]. Two g of a

177 homogenized sample was weighed in a propylene tube. Then $6 \mathrm{ml}$ of $95 \% \mathrm{ACN}$ in water and $2 \mathrm{ml}$

178 of $\mathrm{n}$-heptane were added. The solution was mixed for $5 \mathrm{~min}$ followed by the addition of $0.5 \mathrm{~g}$

$179 \mathrm{NaCl}$ and $0.5 \mathrm{~g} \mathrm{MgSO}_{4}$ and then it was shaken for $30 \mathrm{sec}$. After 5 min centrifugation at $4000 \times \mathrm{g}$,

$18030 \mathrm{mg}$ of PSA SPE bulk sorbent was added to $3 \mathrm{ml}$ of the bottom layer and mixed for $5 \mathrm{~min}$. After

181 centrifugation for $1 \mathrm{~min}$ at $4000 \times \mathrm{g}, 1 \mathrm{ml}$ of the supernatant was evaporated under steam of

182 nitrogen gas. The sample was reconstituted by adding $100 \mu \mathrm{l}$ of $\mathrm{MeOH}$ and $0.9 \mathrm{ml}$ of PBS with $1 \%$

183 BSA. The solution was centrifuged for $5 \mathrm{~min}$ at $4000 \times \mathrm{g}$ and $50 \mu \mathrm{l}$ of non-diluted sample was

184 analysed by the STG ELISA.

186 ELISA validation

187 The validation of the developed STG ELISA was based on the guidance for validation of semi188 quantitative screening methods such as ELISA or quantitative LFD for mycotoxins included in 189 Commission Regulation (EU) 519/2014 [28]. The screening target concentration (STC), which is 190 the concentration of interest for detection of the mycotoxin, was set to $1.5 \mu \mathrm{g} / \mathrm{kg}$. The aim of the 191 validation was to demonstrate the applicability of the STG ELISA for the detection of mycotoxins 192 at the set STC level and higher in 3 types of cereal grains: rice, wheat and maize. This was 
193 accomplished by analysing sets of 20 blank samples and 20 samples spiked at STC for each

194 commodity type. The analysis was performed under intermediate precision conditions by

195 spreading the analysis of these samples over 5 different days. The results were then used to

196 determine 2 parameters: cut-off and false suspected rate. Cut-off is the concentration measured

197 in a sample above which it is classified as "suspect" and it is calculated using the following

198 equation that allows for $5 \%$ rate of false negative result:

199 cut_off $=R_{S T C}-t_{-}$value $_{0.05} \times S D_{S T C}$

200 where RSTc:mean concentration of the positive control samples at STC; $t_{-} v^{2}$ lue $_{0.05}$ one tailed

201 t_value for a rate of false negative results of $5 \%$, which is 1.729 for 20 samples set (19 degrees of

202 freedom); SD sTc:standard deviation at STC. The second parameter, false suspected rate, can be

203 found from a table for t-distribution using a t_value calculated in the following equation:

$204 t_{\_}$value $=\left(\right.$cut $_{\text {off }}-$ mean $\left._{\text {blank }}\right) / S D_{\text {blank }}$

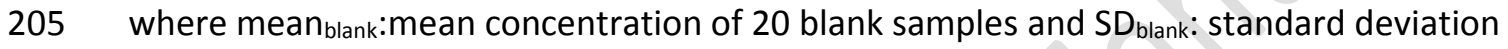

206 calculated for 20 blank samples.

207 During the validation study, sets of 20 samples for each matrix were also spiked at two other 208 concentrations: $3 \mu \mathrm{g} / \mathrm{kg}$ and $6 \mu \mathrm{g} / \mathrm{kg}$ and analysed over five different days to determine recovery 209 and repeatability. The accuracy of the method was tested by analysing naturally contaminated 210 rice samples and comparing the results to these obtained by LC-MS/MS method.

\section{Results and Discussion}

\section{Production of the anti-STG mAb}

215 A spleen from the mouse showing the best titre was used in a fusion experiment resulting in 216 approximately 1800 hybridomas. Three hybridomas were found to produce antibodies with the 217 highest sensitivity to STG and they were selected for further work. Two rounds of cloning were 218 performed before the final monoclonal cell lines were established for each hybridoma selected.

219 They were used to produce mAbs in flask cultures. The antibodies were then concentrated and 220 purified. The stock of each antibody at the concentration of $2 \mathrm{mg} / \mathrm{ml}$ was prepared and 221 characterized using a competitive antigen-coated ELISA. The standard curves for STG were 222 prepared in the range $0.001-1000 \mathrm{ng} / \mathrm{ml}$. The antibody $2 \mathrm{~F} 3$ showed the highest sensitivity and it 223 was selected for the STG ELISA development (Table 2).

225 Table 2. Initial characterization of STG mAbs by competitive antigen-coated ELISA.

$$
\begin{array}{|l|l|l|}
\hline \text { Clone } & \text { Isotype } & \mathrm{IC}_{50} \mathrm{STG}[\mathrm{ng} / \mathrm{ml}] \\
\hline
\end{array}
$$




\begin{tabular}{|l|l|l|}
\hline 2F3 & IgG2a, $\mathrm{k}$ & 0.99 \\
\hline 3F5 & $\operatorname{IgG1}, \mathrm{k}$ & 53.9 \\
\hline 8F11 & $\operatorname{IgG2a}, \mathrm{k}$ & 45.2 \\
\hline
\end{tabular}

\section{Sensitivity and cross-reactivity}

228 The mAb specific to STG was used to develop a direct competitive ELISA. A seven-point standard 229 curve was prepared in buffer for STG at 0, 0.125, 0.25, 0.5, 1, 2 and $4 \mathrm{ng} / \mathrm{ml}$. A typical standard 230 curve is presented in Fig. 2. The mean $\mathrm{IC}_{50}$ was $0.64 \pm 0.02 \mathrm{ng} / \mathrm{ml}$. The cross-reactivity with 231 aflatoxins $B_{1}, B_{2}, G_{1}, G_{2}$ and $M_{1}$ was below $1 \%$ indicating suitability of the developed assay for the 232 specific detection of STG. Therefore, the occurrence of aflatoxins in samples analysed by STG 233 ELISA should not lead to any false positive results.

\section{ELISA validation}

236 For validation, sets of blank samples and blank samples spiked at $1.5 \mu \mathrm{g} / \mathrm{kg}$ for each matrix were analysed over five different days. For each matrix there was a complete separation between blank and spiked samples (Fig. 3.). The calculated false suspected rates were $0.34 \%, 1.15 \%$ and $0.78 \%$ (Table 3), meaning that on average less than 1 sample in 100 might be wrongly classified as containing more than $1.5 \mu \mathrm{g} / \mathrm{kg}$ of STG, requiring unnecessary analysis by a confirmatory method. The results of the recovery and repeatability study for the STG ELISA are presented in Table 4. The recovery was determined in samples spiked at 1.5, 3 and $6 \mu \mathrm{g} / \mathrm{kg}$. The mean recovery was in the range 88 and $127 \%$ and the CV was lower than $20.3 \%$.

Table 3. Results of the validation study according to the guidance included in Commission Regulation (EU) 519/2014 [24].

\begin{tabular}{|l|c|c|c|}
\hline & STC $[\mu \mathrm{g} / \mathrm{kg}]$ & Cut-off $[\mu \mathrm{g} / \mathrm{kg}]$ & False suspected rate [\%] \\
\hline Rice & 1.5 & 1.2 & 0.34 \\
\hline Wheat & 1.5 & 1.2 & 1.15 \\
\hline Maize & 1.5 & 1.3 & 0.78 \\
\hline
\end{tabular}

The ELISA presented within this communication demonstrates important improvements when compared to the limited number of published methods for STG (Table 1). The developed method, a direct competitive ELISA, requires fewer steps than the indirect competitive ELISAs developed so far, therefore it is much easier to perform. In addition, the sample preparation method does

252 not involve an expensive and time-consuming immunoaffinity chromatography step. The 253 developed sample extraction procedure was adapted from the method developed by Zhao et al. 
254 [13] and is based on a modified QuEChERS approach. In this method magnesium sulphate and sodium chloride are first added to a sample extracted with $95 \%$ ACN to reduce water content and then primary-secondary amine (PSA) is used to remove interfering compounds. A small amount of PSA sorbent is added directly to the sample extract, mixed and then removed by centrifugation. This procedure is much faster and easier to perform compared to methods involving the use of columns packed with PSA sorbent. PSA was shown to reduce matrix effects as it is a weak anion exchanger and can bind fatty acids, some pigments, carbohydrate and organic acids. The method was successfully applied for the extraction of STG from rice, wheat and maize matrices. Due to the application of this sample preparation procedure, the matrix effects were reduced allowing for the sensitive detection of STG.

Table 4. Recovery and CV for the STG ELISA ( $n=20$ at each level).

\begin{tabular}{|c|c|c|c|c|}
\hline Matrix & $\begin{array}{c}\text { Spiking level } \\
{[\mu \mathrm{g} / \mathrm{kg}]}\end{array}$ & $\begin{array}{c}\text { Mean concentration } \pm \text { SD } \\
{[\mu \mathrm{g} / \mathrm{kg}]}\end{array}$ & $\begin{array}{c}\text { Mean recovery } \pm \text { SD } \\
{[\%]}\end{array}$ & $\begin{array}{c}\mathrm{CV} \\
{[\%]}\end{array}$ \\
\hline \multirow{4}{*}{ Rice } & 1.5 & $1.9 \pm 0.4$ & $126 \pm 24$ & 19.5 \\
\cline { 2 - 5 } & 3 & $3.2 \pm 0.4$ & $105 \pm 13$ & 12.7 \\
\cline { 2 - 5 } & 6 & $5.5 \pm 0.7$ & $92 \pm 12$ & 13.3 \\
\hline \multirow{4}{*}{ Wheat } & 1.5 & $1.8 \pm 0.4$ & $120 \pm 24$ & 20.3 \\
\cline { 2 - 5 } & 3 & $3.0 \pm 0.4$ & $101 \pm 12$ & 11.6 \\
\cline { 2 - 5 } Maize & 6 & $5.6 \pm 0.8$ & $93 \pm 13$ & 13.9 \\
\cline { 2 - 5 } & 1.5 & $1.9 \pm 0.3$ & $127 \pm 23$ & 17.9 \\
\cline { 2 - 5 } & 3 & $3.1 \pm 0.4$ & $105 \pm 13$ & 12.5 \\
\hline
\end{tabular}

\section{Analysis of naturally contaminated samples}

268 In order to further characterize the developed method, seven naturally contaminated rice 269 samples were analysed by the STG ELISA and the results were compared to these obtained by an 270 LC-MS/MS method [20]. The correlation coefficient was found to be 0.9851 , indicating a very 271 good accuracy of the STG ELISA (Fig. 4).

\section{Conclusions}

274 A new mAb against STG toxin was prepared and used to develop a direct competitive ELISA with 275 an $\mathrm{IC}_{50}$ of $0.64 \mathrm{ng} / \mathrm{ml}$ and no cross-reactivity with aflatoxins. A sample preparation method for 276 efficient STG extraction from cereals: wheat, maize and rice was developed and optimized 277 without the need for any time-consuming sample purification strategies such as solid phase 278 extraction or immunoaffinity chromatography. The required sensitivity was achieved by using a 
279 modified QuEChERS approach with PSA sorbent applied to reduce matrix effects. The assay was

280 validated in accordance with the guidelines for validation of semi-quantitative screening

281 methods for mycotoxins included in Commission Regulation (EU) 519/2014 [24]. The STC was set

282 at $1.5 \mu \mathrm{g} / \mathrm{kg}$ and the method was validated for the detection of STG at a level of STC and above

283 with low false suspected rate. The recovery was also determined at different levels and it was

284 between 88 and $127 \%$ with the CV lower than $20.3 \%$. Good accuracy of the STG ELISA was

285 demonstrated by comparing the results obtained by ELISA and LC-MS/MS method for naturally

286 contaminated samples. The new ELISA can be applied for sensitive and high-throughput

287 screening for the presence of STG in cereals.

288

289 Acknowledgements

290 This project has received funding from the European Union's Horizon 2020 research and

291 innovation programme under the Marie Sklodowska-Curie grant agreement No 655119.

292 The authors would like to thank Lucia Streppel and Piet van Wichen from EuroProxima for their 293 support of this research.

\section{Compliance with ethical standards}

296 Conflict of Interest The authors declare no conflict of interest.Research involving animals Animal 297 experiments were performed in accordance with the UK Animals Scientific Procedures Act 1986 298 under the license PPL2756 issued on the 12/02/2014 by the Department of Health, Social Services 299 and Public Safety for Northern Ireland. The study received approval from the Queens University 300 Belfast Animal Welfare and Ethical Review Body on 09/01/2014.

\section{References}

302 [1] Bhat R, Rai RV, Karim AA. Mycotoxins in food and feed: present status and future concerns. Compr Rev Food Sci F. 2010;9:57-81.

304 [2] European Commission. Commission Regulation (EC) No 1881/2006 of 19 December 2006 setting maximum levels for certain contaminants in foodstuffs. Off J Eur Union. 2006;L364:5-23.

[3] European Commission. Commission Recommendation of 17 August 2006 on the presence of deoxynivalenol, zearalenone, ochratoxin A, T-2 and HT-2 and fumonisins in products intended for animal feeding (2006/576/EC). Off J Eur Union. 2006;L229:7-9. 
[4] European Commission. Commission Recommendation of 27 March 2013 on the presence of T-2 and HT-2 toxin in cereals and cereal products (2013/165/EU). Off J Eur Union. 2013;L91:12-15.

[5] International Agency for Research on Cancer (IARC). Chemical agents and related occupations. A review of human carciongens. In: IARC Monographs on the Evaluation of Carcinogenic Risks to Humans. 2012;100F:225-244.

[6] European Food Safety Authority (EFSA). Scientific Opinion on the risk for public and animal health related to the presence of sterigmatocystin in food and feed. EFSA Journal. 2013;11(6):3254.

[7] Veršilovskis A, De Saeger S. Sterigmatocysin: Occurrence in foodstuffs and analytical methods - An overview. Mol Nutr Food Res. 2010;54:136-147.

[8] International Agency for Research on Cancer (IARC). Some naturally occurring substances. In: IARC Monographs on the Evaluation of Carcinogenic Risks to Humans. Summaries and Evaluations. 1987;10:72.

[9] Stroka J, Dasko L, Spangenberg B, Anklam E. Determination of the mycotoxin, sterigmatocystin, by thin-layer chromatography and reagent-free derivatisation. J Liq Chromatogr Relat Techno. 2004;27:2101-2111.

[10] Mol HGJ, Pietri A, MacDonald SJ, Anagnostopoulos C, Spanjer M. Survey on sterigmatocystin in food. EFSA supporting publication. 2015;EN-774:56.

[11] Veršilovskis A, Bartkevičs V, Mikelsone V. Sterigmatocystin presence in typical Latvian grains. Food Chem. 2008;109:243-248.

[12] Marley E, Brown P, Mackie J, Donnelly C, Wilcox J, Pietri A, Macdonald S. Analysis of sterigmatocystin in cereals, animal feed, seeds, beer and cheese by immunoaffinity column clean-up and HPLC and LC-MS/MS quantification. Food Addit Contam A. 2015;32: 2131-2137.

[13] Zhao Y, Huang J, Ma L, Wang F. Development and validation of a simple and fast method for simultaneous determination of aflatoxin B1 and sterigmatocystin in grains. Food Chem. 2017;221:11-17.

[14] Ok HE, Tian F, Hong EY, Paek O, Kim S-H, Kim D, Chun HS. Harmonized collaborative validation of aflatoxins and sterigmatocystin in white rice and sorghum by liquid chromatography coupled to tandem mass spectrometry. Toxins. 2016;8:371.

[15] Biancardi A, Dall'Asta C. Determination of sterigmatocystin in feed by LC-MS/MS. Food Addit Contam. 2015;32:2093-2100. 
[16] Sulyok M, Krska R, Schuhmacher RA. A Liquid chromatography/tandem mass spectrometric multi-mycotoxin method for the quantification of 87 analytes and its application to semiquantitative screening of moldy food samples. Anal Bioanal Chem. 2007;389:1505-1523.

[17] Monbaliu S, Van Poucke C, Detavernier C, Dumoultn F, Van Velde MDE, Schoeters E, Van Dyck S, Averkieva O, Van Peteghem C, De Saeger S. Occurrence of mycotoxins in feed as analysed by a multi-mycotoxin LC-MS/MS method. J Agr Food Chem. 2010;58:66-71.

[18] Jackson LC, Kudupoje MB, Yiannikouris A. Simultaneous multiple mycotoxin quantification in feed samples using three isotopically labeled internal standards applied for isotopic dilution and data normalization through ultra-performance liquid chromatography/electrospray ionization tandem mass spectrometry. Rapid Commun Mass Sp. 2012;26:2697-2713.

[19] Malachová A, Sulyok M, Beltrán E, Berthiller F, Krska, R. Optimization and validation of a quantitative liquid chromatography-tandem mass spectrometric method covering 295 bacterial and fungal metabolites including all regulated mycotoxins in four model food matrices. J Chromatogr A. 2014;1362:145-156.

[20] Oplatowska-Stachowiak M, Haughey SA, Chevallier OP, Galvin-King P, Campbell K, Magowan E, Elliott CT. Determination of the Mycotoxin Content in Distiller's Dried Grain with Solubles Using a Multianalyte UHPLC-MS/MS Method. J Agr Food Chem. 2015;63:9441-9451.

[21] Kong D, Xie Z, Liu L, Song S, Kuang H, Cui G, Xu C. Development of indirect competitive ELISA and lateral-flow immunochromatographic assay strip for the detection of sterigmatocystin in cereal products. Food Agr Immunol. 2017;28:260-273.

[22] Li M, Li P, Wu H, Zhang $Q$, Ma F, Zhang Z, Ding $X$, Wang $H$. An ultra-sensitive monoclonal antibody-based competitive enzyme immunoassay for sterigmatocystin in cereal and oil products. PLOS ONE. 2014;9:e106415.

[23] Li S, Chen, PY, Marquardt RR, Han Z, Clarke JR. Production of a sensitive monoclonal antibody to sterigmatocystin and its application to ELISA of wheat. J Agr Food Chem. 1996;44:372-375.

[24] European Commission. Commission Regulation (EU) 519/2014 of 16 May 2014 amending Regulation (EC) No 401/2006 as regards methods of sampling of large lots, spices and food supplements, performance criteria for T-2, HT-2 toxin and citrinin and screening methods of analysis. Off J Eur Union. 2014;L147:29-43.

[25] Kononenko GP, Burkin AA, Soboleva NA. Comparative characterization of immune reagents based on hemiacetals of aflatoxin B1 and sterigmatocystine. Appl Biochem Micro. 2002;38:487-492. 
376 [26] Oplatowska-Stachowiak M, Sajic N, Xu Y, Haughey SA, Mooney MH, Gong YY, Verheijen R, Elliott CT. Fast and sensitive aflatoxin B1 and total aflatoxins ELISAs for analysis of peanuts, maize and feed ingredients. Food Control. 2016;63:239-245.

379 [27] Köhler G, Milstein C. Continuous cultures of fused cells secreting antibody of predefined specificity. Nature. 1975;256:495-497.

381 [28] Oplatowska-Stachowiak M, Kleintjens T, Sajic N, Haasnoot W, Campbell K, Elliott CT, Salden M. T-2 toxin/HT-2 toxin and ochratoxin A ELISAs development and in-house validation in 
<smiles>C=CCCCC</smiles>
aflatoxin $B_{1}$<smiles>COc1cc2c(c3oc(=O)c4c(c13)CCC4=O)C1CCOC1O2</smiles>

aflatoxin $\mathrm{B}_{2}$<smiles>COc1cc2c(c3oc(=O)c4c(c13)CCOC4=O)C1C=COC1O2</smiles>

aflatoxin $G_{1}$<smiles>COc1cc2c(c3oc(=O)c4c(c13)CCOC4=O)C1CCOC1O2</smiles>

Fig. 1. The structures of sterigmatocystin and aflatoxins.

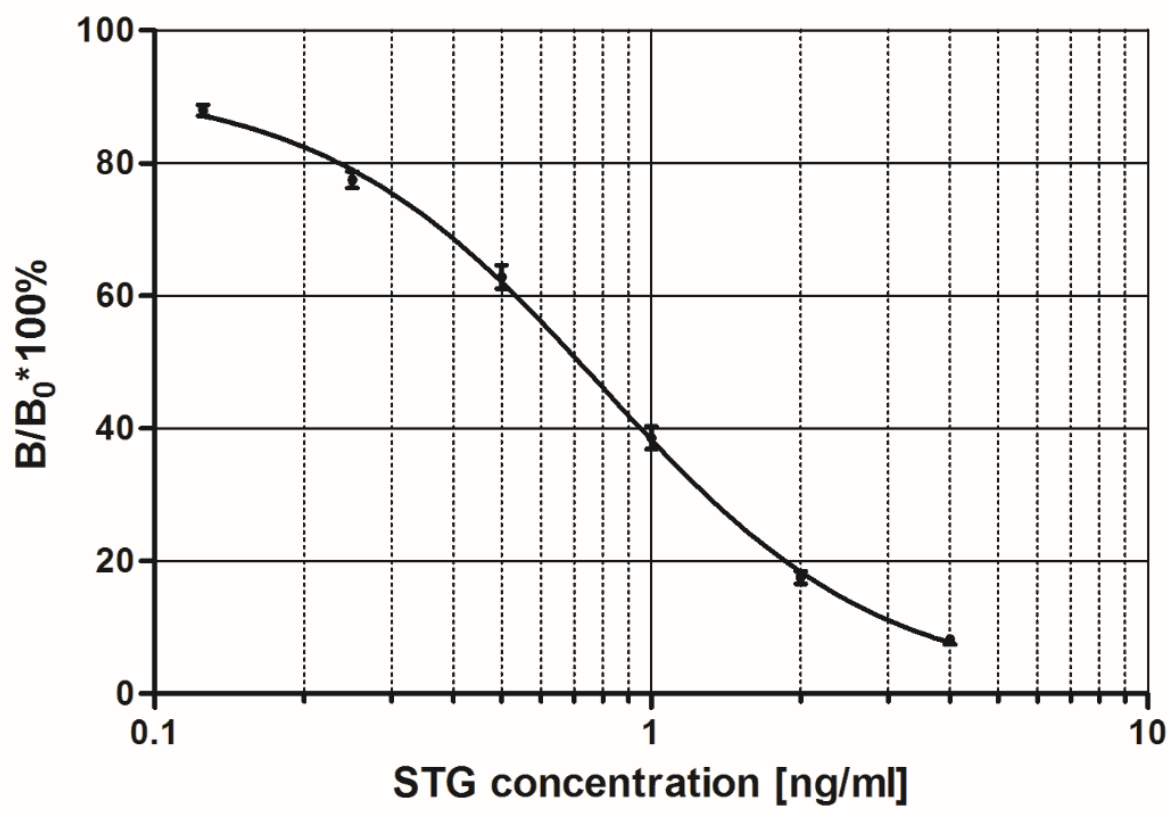

Fig. 2. Typical standard curve for STG in the STG ELISA in buffer $(n=12)$. 

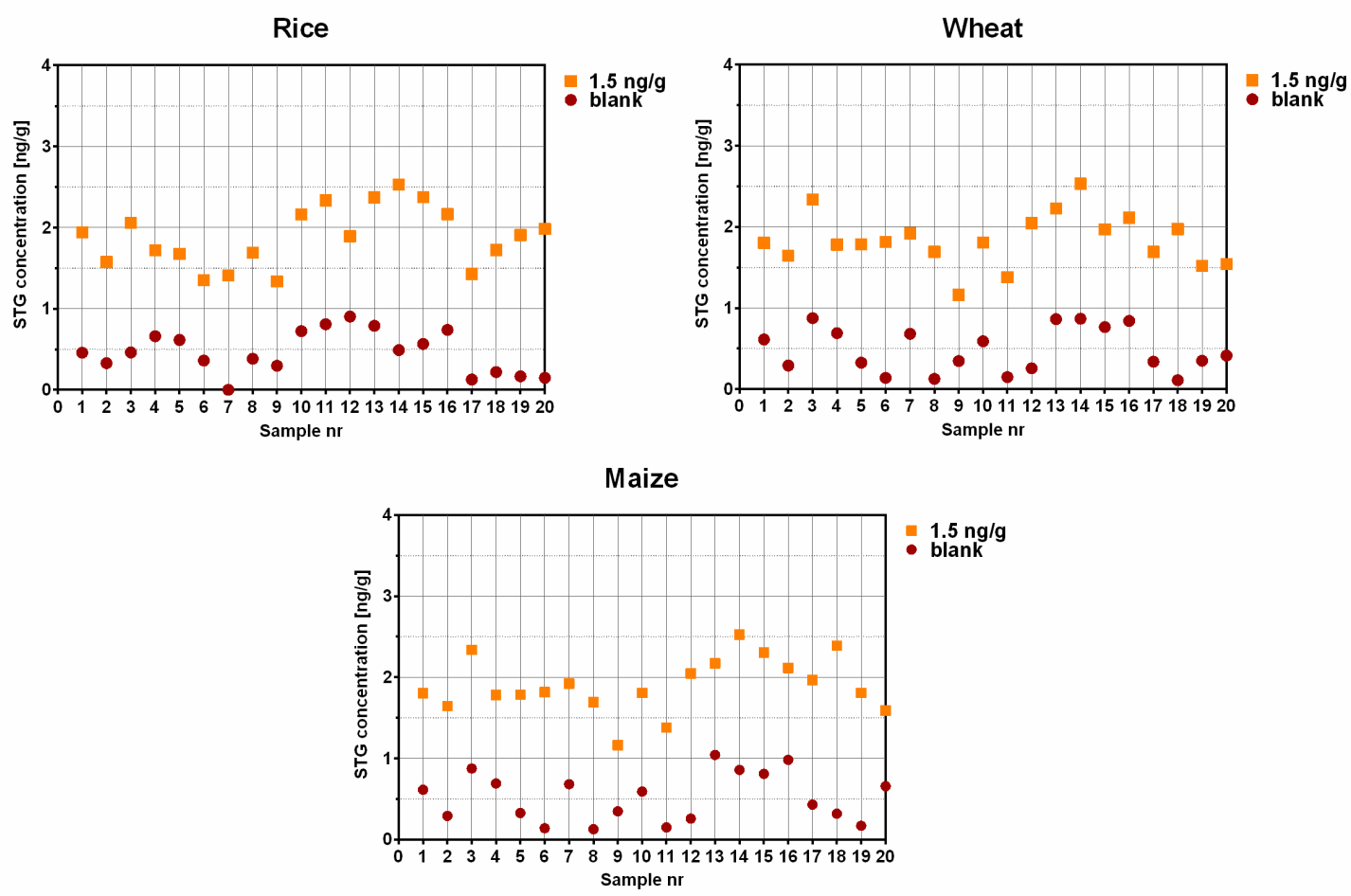

Fig. 3. Concentrations of STG found with the STG ELISA in blank and $1.5 \mu \mathrm{g} / \mathrm{kg}$ spiked samples of 392 rice, wheat and maize $(n=20)$.

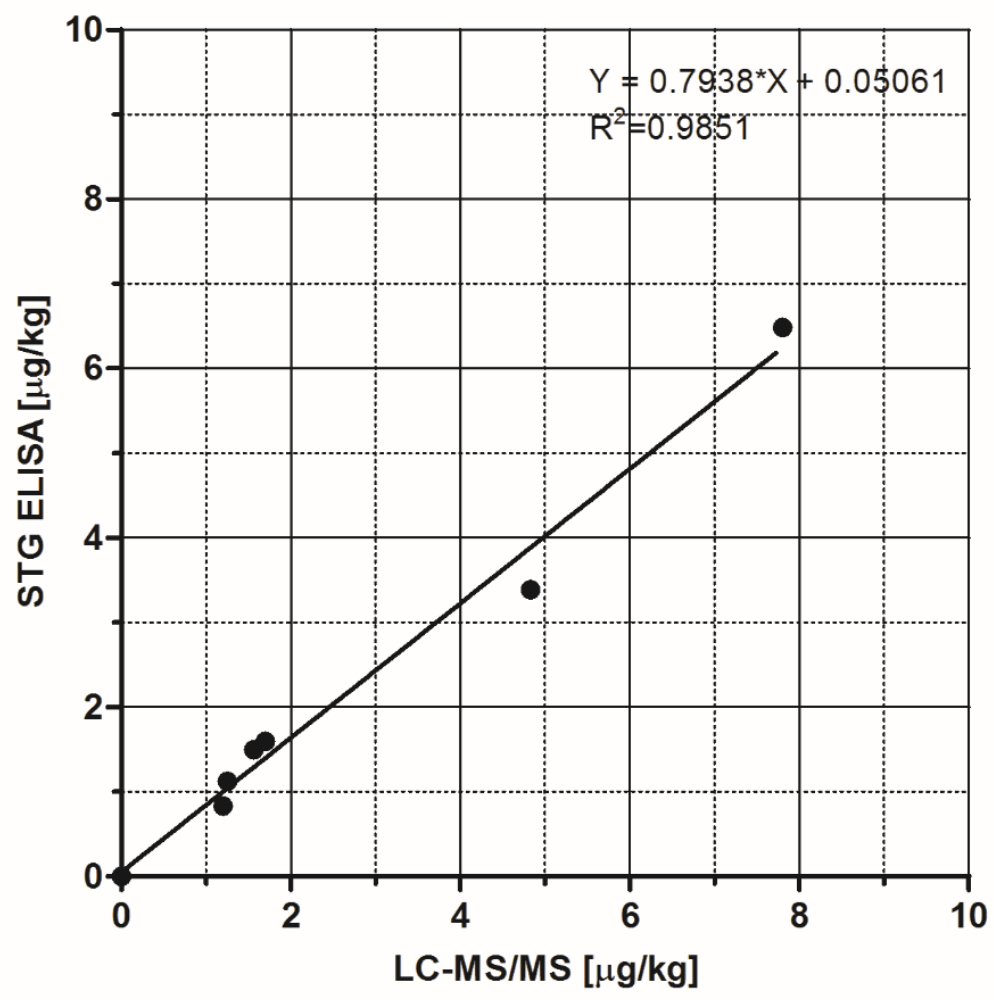

Fig. 4. Correlation of the results obtained for naturally contaminated rice samples by the STG ELISA and LC-MS/MS. 